ARTIKEL

\title{
MEMBANGUN GERAKAN INKLUSIVISME MODEL JAMAAH PERSATUAN ISLAM
}

\author{
M. Taufiq Rohman, Beni Ahmad Saebani \\ Universitas Islam Negeri Sunan Gunung Djati Bandung \\ fikrakoe@uinsgd.ac.id, beniuin@yahoo.com
}

\begin{abstract}
This article discusses the emergence of the inclusivist movement in religious social movements. With a qualitative method the article finds that the religious organization of Islamic Unity (abbr.: Persis) which in fact is an exclusive organization in Indonesia bas turned into an inclusive one when dealing with other parties, especially in neighboring life, nation and state. The current social style of Persis shows a fairly friendly face of Islam, not hostile as it once was. This is seen as a survival scheme of the organization, so it always exists and can still adjust to the challenges of the times
\end{abstract}

Keyword: Religious Movement, Islamic Unity, Inclusive Social Life

\begin{abstract}
Abstrak
Artikel ini membahas tentang munculnya gerakan inklusivisme dalam gerakan sosial keagamaan. Dengan metode kualitatif artikel ini menemukan bahwa organisasi keagamaan Persatuan Islam yang notabene sebuah organisasi eksklusif di Indonesia telah berubah menjadi inklusif manakala berhadapan dengan pihak-pihak lain, terutama dalam kehidupan ketetanggaan, berbangsa dan bernegara. Gaya kehidupan sosial Persis saat ini menunjukkan wajah Islam yang cukup ramah, tidak bersifat permusuhan seperti dulu. Hal ini dilihat sebagai skema survival dari organisasi tersebut, sehingga selalu eksis dan tetap dapat menyesuaikan dengan tantangan zaman
\end{abstract}

Kata Kunci: Gerakan Keagamaan, Persatuan Islam, Kehidupan Sosial Inklusif

\section{A. Pendahuluan}

Ajaran agama memiliki pengaruh yang besar dalam menyatukan persepsi kehidupan masyarakat tentang semua harapan hidup. Agama merupakan salah satu arah kehidupan sosial yang proses pemolaannya lebih sistematis dan mendarah daging. Dalam pemolaan perilaku sosial agama memasuki hati nurani manusia, sehingga akal pikiran utama mencari makna hidup belumlah sempurna apabila substansi ajaran agama tidak dijadikan rujukan terpenting secara epistemologis maupun aksiologis (Hamka, 1989).

Kesamaan ideologis dalam beragama disosialisasikan melalui wadah yang dibangun dengan citarasa yang sama, sehingga terbentuklah organisasi atau institusi yang dengan proses terus menerus dan dengan sistem kepemimpinan yang dilegitimasi 
oleh doktrin agama, perilaku sosial keagamaan itu menjadi kolektif dengan homogenitas perilaku yang sangat dominan. Segala potensi dan dinamika kultural individual sebagai fitrah manusia serta variasi kepentingan personal diluluhkan oleh kepentingan institusional tersebut, yang kemudian sukar dibedakan antara perilaku diri atau perilaku institusi (Rahman, 2010).

Tindakan yang memiliki kekuatan struktural dapat diwariskan kepada generasi berikutnya yang secara realitas tidak memerlukan alasan-alasan rasional, karena tindakan itu melembaga dan menebarkan daya ikat kultural yang kuat. Tolok ukur tindakan itu adalah komitmen dan loyalitas anggota dan masyarakat partisipan yang solid kepada institusi tersebut. Tindakan yang telah terbentuk dan diintegrasikan akan diyakini sebagai perilaku religius yang menjadi tujuan masyarakat dalam beragama. Irrasionalitas dalam beragama adalah perilaku yang rasional (Weber, 1966) dan sebagai jawaban jauhnya jarak antara masyarakat dengan Tuhan yang menjadi tujuan utama.

Organisasi keagamaan yang ada di Indonesia, misalnya Nahdatul Ulama (NU) Persatuan Islam (Persis) dan Muhammadiyah adalah institusi agama yang memiliki ciri khas dan tradisi masing-masing. Perbedaan perilaku sosial itu diduga karena perbedaan paradigma, baik dalam pemahaman keagamaan, sistem organisasi maupun pola kepemimpinannya. Pendekatan dalam memahami teks-teks ajaran agama diduga dapat menciptakan perilaku religius yang berlainan. Bahkan karena berbeda menerjemahkan satu kata dalam al-Qur’an, yang merupakan kitab suci agama Islam, dapat melahirkan perbedaan perilaku ritual tertentu.

Persatuan Islam, sebagai organisasi keagamaan yang usianya cukup tua sudah banyak dikaji dan diteliti, Federspiel (1970) memandang sejarah lahirnya Persatuan Islam sebagai pembaharuan yang dipengaruhi oleh gerakan politik dari pemikiran Muhammad Abduh yang kelahirannya menciptakan gerakan kultural konfrontatif, secara kultural maupun intelektual, di saat organisasi Islam lain melestarikan aktivitas keagamaan yang bernuangsa hinduistik dengan cara berfikir tradisional. Persatuan Islam lahir untuk memberantas cara berfikir tradisional dengan digantikan oleh cara berfikir rasional dan puritan. Federspiel menyimpulkan bahwa Persis adalah organisasi Islam yang melakukan pembaharuan dan pemurnian dalam bidang teologi, fiqh, pendidikan, dan dakwah. Penelitian Chalijdah Hasan (1990) dan Salim Umar (1995) berkaitan dengan Persis dari sisi pembaharuan yang dilakukan Persis pengaruhnya 
terhadap aspek akidah dan aspek sosial keagamaan di masyarakat Jawa Barat. Kedua peneliti itu berkesimpulan bahwa reformasi yang dilakukan persis dalam akidah maupun ibadah yang berpegang kepada prinsip-prinsip ajaran Islam yang kuat telah berpengaruh kuat terhadap perilaku penganutnya.

Persatuan Islam dikenal sebagai organisasi yang menyuarakan pembaharuan dengan dorongan dan pengaruh pemikiran pembaharuan kelompok muslim modernis yang dipelopori oleh Ibnu Taimiyah (1263-1328), dilanjutkan Ibnu Qayyim (1292-1350) dan Muhammad bin Abdul Wahab (1845-1905). Pemikiran yang dikembangkan adalah bahwa Islam sepenuhnya sesuai dengan perkembangan ilmu pengetahuan dengan teknologi. Islam menyeru agar manusia menggunakan akalnya untuk berfikir, memgkaji ilmu dan menerapkannya dalam kehidupan sehari-hari di masyarakat dengan mengacu kepada ide-ide fundamental al-Qur'an (Wawancara dengan DT, pengurus pusat Persis, 2/7/2017).

Perilaku yang melembaga adalah kehendak organisasi, tetapi ia lahir dari berbagai macam perkembangan, baik perkembangan metodologi penggalian ajaran Islam maupun pengaruh kharismatika pemimpin atau kondisi politik yang berkecamuk dalam tubuh organisasi. Pemahaman itu dapat ditafsirkan bahwa perilaku institusional adalah bagian dari proses fanatisme dan taklid. Anggapan ini disebabkan oleh adanya variasi ilmu agama yang dimiliki anggota Persis atau sumber daya manusia yang heterogen (Wawancara dengan IL, pengurus pusat Persis, 2/7/2017).

Solidaritas lebih banyak terkait dengan persoalan-persoalan sosial, di antara jamaah Persis ada ikatan emosional yang dalam, sebagaimana adanya rasa kesamaan ideologis. Tetapi dalam konteks pemahaman keagamaan di kalangan jamaah Persis, terlebih jamaah yang secara intelektual memiliki dasar-dasar keilmuan yang cukup mumpuni, solidaritas intelektual tidak mudah begitu saja mencair menjadi satu dan terintegrasikan. Pada jamaah Persis tradisi debat dan polemik dengan sesama jamaah sukar dihilangkan, dan ini pun dapat melahirkan perilaku keagamaan dan ritual yang berbeda. Pendekatan dalam menggali pesan-pesan Allah dan Rasul, dalam al-Qur'an atau al-Hadits untuk kalangan jamaah Persis tertentu diberikan kebebasan berwacana, meskipun dalam tubuh organisasi ada tim ahli yang memiliki kewenangan secara struktural maupun intelektual, yakni Dewan Hisbah Persatuan Islam (Wawancara dengan DT, pengurus pusat Persis, 2/7/2017). 
Perbedaan perilaku keagamaan muncul, salah satunya karena penyusunan argumentasi yang secara metodologis berbeda. Jika hal itu terjadi, perilaku tidak begitu saja terinstitusikan secara kolektif dan homogen. Dengan demikian paradigma pemahaman atas sumber ajaran Islam ikut menentukan terlembagakan tidaknya perilaku keagamaan jamaah Persis. Lebih jauh lagi, di kalangan jamaah Persis yang cukup intelek, institusi bukan alat mutlak yang menyeragamkan sekaligus melembagakan perilaku keagamaannya. Dapat kiranya dipertegas di sini, bahwa tidak ada kaitan langsung antara pemimpin Persis dan kharismatikanya dengan terlembagakannya perilaku sosial keagamaan jamaah Persis (Wawancara dengan AM, pengurus pusat Persis, 2/7/2017).

\section{B. Tinjauan Teori}

Perilaku institusional dapat dikatakan sebagai perilaku komunitas yang bersifat patembayan, karena diorganisasikan oleh peraturan, keputusan dan sistem manajerial yang berlaku pada institusi bersangkutan. Akan tetapi, meskipun perilaku institusi ini bersifat patembayan apabila berkaitan dengan hal-hal yang religius, akan mengambil sedikitnya pola perilaku paguyuban, karena ikatan emosional keberagamaan tidak hanya ditentukan oleh sistem organisasi, tetapi juga dibentuk oleh pola partisipatif dari dorongan ideologis (Rahman, 2010). Perilaku sosial keagamaan dapat merupakan karakteristik kultural yang diinstitusionalisasikan melalui enam karakter budaya, sebagaimana Fred Luthans (2011) mengaturnya sebagai berikut:

Proses saling belajar dalam berbudaya melalui interaksi dalam masyarakat yang terorganisir atau masyarakat yang kompleks;

1. Proses saling berbagi budaya (shared culture) di antara anggota organisasi;

2. Proses saling mewariskan budaya dari generasi ke generasi berikutnya;

3. Proses simbolisasi perilaku yang dipandang representatif bagi integrasi kultural organisatoris;

4. Proses pembentukan dan pengintegrasian perilaku sosial; dan

5. Proses adaptasi dari semua perilaku masyarakat institusional, yang memperkuat heterogenitas perilaku, sebaliknya memperlemah dinamika persepsi dan tindakan sosial. 
Proses institusionalisasi perilaku sosial keagamaan berjalan melalui enam tahapan tersebut kemudian menjadi karakter keagamaan yang integratif, baik pada pola perilakunya maupun pada berbagai aspek yang mendukung pemolaan perilaku sosial keagamaan yang bersangkutan. Sumber perilaku sosial lebih besar didominasi oleh fanatisme terhadap sumber ajaran yang berlaku dan diyakini oleh pemeluknya. Teksteks ajaran agama dipahami dengan pendekatan linguistik, terutama dalam mengungkapkan makna, maksud dan berbagai ketentuan hukum yang terdapat di dalamnya, sehingga dari teks-teks kitab suci dapat dimaknai dengan berbagai istilah yang berlaku dalam hukum perilaku. Pesan-pesan tekstual yang telah tergali kandungan makna hukumnya disebut dengan al-abkam al-khamsah (lima macam hukum) (Rahman, 2016).

Institusionalisasi lebih didominasi oleh seperangkat norma yang mengekalkan simbol-simbol budaya yang telah terintegrasikan melalui berbagai dimensinya. Integrasi semua potensi sosial kemungkinan lebih melekat ketika berbagai kepentingan individu yang sifatnya personal berinteraksi secara timbal balik dan fungsional.

Institusi agama bukan hanya menumpuk norma-norma, bukan sekadar lembaga atau organisasi, tetapi norma dan sistem nilai yang melahirkan lembaga yang mewadahi keyakinan menusia serta menyeragamkan perilaku dengan visi agamis. Pada banyak kasus, menurut Hodgson (2009), dapat dilihat dampak tradisi-tradisi serta norma-norma hasil pemahaman dan penafsiran atas ajaran agama, terutama terhadap kreativitas personal sebagai hal yang mengekang ekspresi kreatif individu. Dengan sedikitnya batasan-batasan yang diberikan oleh gaya dan tradisi, dimungkinkan adanya sejumlah besar kreativitas yang secara sosiologis tidak terbatasi.

Agama direduksikan ke dalam beberapa hal mendasar, yang kemudian diyakini bersumber langsung dari Tuhan sebagai pembuat hukum. Beberapa hal tersebut adalah:

1. Keyakinan terhadap ajaran-ajaran suci, tentang Tuhan dan dzat ghaib yang oleh ajaran agama wajib diyakini eksistensinya;

2. Seorang atau kebanyakan pemeluk agama "tidak begitu mengerti" tentang asal usul keyakinan itu tumbuh;

3. Kecuali karena keluarga yang mewariskan agama, lingkungan memberikan pengaruh atas tumbuh dan berkembangnya suatu keyakinan; 
4. Bagi pemeluk agama Islam sumber ajaran, yakni al-Qur'an dan al-Sunnah adalah hal yang irrasional, karena rangkaian ayat atau perkataan Nabi Muhammad saw. mengalami perjalanan yang cukup panjang sehingga sampai ke tengah-tengah masyarakat dewasa ini, maka jika keyakinan tidak tumbuh, kemungkinan besar "sikap beragama, fanatisme agama" pun sukar untuk dimiliki manusua. Pada umumnya keyakinan ditumbuhkan oleh keadaan lingkungan, sangat jarang yang tumbuh secara tiba-tiba;

5. Pemahaman atau penafsiran atas al-Qur'an dan al-Sunnah adalah cara pertama mempertebal keyakinan atas agama dan semua ajaran-ajarannya;

6. Terdapat orang-orang tertentu yang memiliki hak prerogatif untuk menafsirkan ajaran Islam;

7. Hasil penafsiran atas ajaran agama diwadahi oleh lembaga-lembaga agama kemudian disosialisasikan kepada masyarakat, terutama anggota suatu lembaga agama itu sendiri;

8. Disebabkan lembaga-lembaga agama itu berlainan paradigma, maka pelaksanaan ajaran agama pun tidak ada yang sama;

9. Ketidaksamaan terlihat dalam simbol-simbol keagamaan;

10. Organisasi semakin memperjelas perbedaam paradigma dan pelaksanaan praktek agamais;

11. Ulama adalah "penguasa" agama yang diikuti oleh murid-muridnya, bahkan masyarakat beragama yang awwam;

12. Berbagai rujukan yang ditulis dalam bahasa Arab memberikan petunjuk bahwa Islam berasal dari bangsa yang menggunakan bahasa Arab sebagai bahasa ibu;

13. Karena bahasa Arab adalah juga bahasa yang digunakan oleh dan untuk alQur'an dan al-Sunnah, maka belajar bahasa Arab menjadi alat utama untuk dapat menggali pesan-pesan Allah dan Rasul-Nya; dan

14. Para pemikir atau mujtahidin dapat melakukan penafsiran atas ajaran agama, kemudian berbagai fasilitas pendidikan agama mengajarkan bahasa Arab sebagai bahasa yang wajib dipelajari secara mendalam (Ash-Shiddieqy, 1997).

Dengan pandangan-pandangan di atas, Bryan S. Turner (1991) berpendapat, bahwa perilaku institusional dan pengarahan terhadap pemeluk agama akan berkaitan dengan keyakinan, simbolisasi yang membuktikan keyakinan empirik, kitab yang 
memberi rumus untuk berkomunikasi dengan sang Pencipta, serta ajaran lainnya yang membentuk cara berperilaku bagi pemeluk agama. Akan menjadi sangat khas manakala wadah agama dan pemeluk-pemeluknya adalah lembaga masyarakat dan keagamaan. Hal demikian dipandang sebagai perwujudan structural normative dalam beragama. Artinya semua sistem yang terdapat dalam agama, semacam sistem ritus dan sistem credo telah dipersempit oleh lembaga yang dimaksudkan. Oleh karena itu kerangka berpikir yang digunakan dalam konteks perilaku institusional beragama adalah yang dibangun oleh fungsi-fungsi struktural, fungsi kepemimpinan, penghayatan, dan pemahaman terhadap ajaran agama, serta pola interaksi di antara pemeluk agama yang ada dalam lembaga tertentu, dan cara-cara pengamalan ajaran agama.

Di Indonesia, interaksi antarumat beragama diarahkan oleh ajaran-ajaran agama sendiri, sehingga kemungkinan diarahkan oleh norma-norma yang berlaku sangat dominan. Tradisi dan kebudayaan lokal, dapat diartikan juga sebagai salah satu dari penganut agama dengan label organisasi masyarakat dan keagamaan tempat pemeluk agama itu beraktivitas. Adaptabilitas dalam perilaku keagamaan sengaja dibentuk atau terbentuk karena interaksi yang satu arah (Rahman, 2014).

Proses mengarahkan perilaku sehingga menjadi homogen adalah bagian dari visi dan missi dalam lembaga keagamaan, dengan demikian sumber ajaran agama tidak secara serta merta dijadikan pedoman pertama dalam berperilaku. Hak demikian diidentifikasikan oleh banyaknya anggota suatu lembaga keagamaan yang awam, sehingga perilaku ritual atau sosial keagamaannya tidak didasarkan kepada argumentasi melainkan oleh sikap imitatif (taqlid) kepada pemeluk agama lainnya. Secara berkesinambungan pewarisan taqlid atau perilaku imitatif berlaku pada setiap pemeluk agama dalam suatu institusi tertentu, tidak terkecuali organisasi agama yang menyatakan sebagai pembaharu. Bagi anggota yang awam tentang alat dan perangkat ilmiah untuk menggali sumber ajaran Islam, sikap taqlid menjadi lumrah, bahkan wajib (Ash-Shiddieqy, 1997). Padahal dalam konteks teori sistem sosial, perilaku demikian adalah bagian dari sikap adaptasi dalam mencapai tujuan. 


\section{Pembahasan}

Sebagai ormas Islam, Persis mendidik hidup berjamaah, berimamah, dan berimarah, tunduk dan taat kepada niz̧ham (peraturan) yang sejalan dengan al-Qur'an dan al-Sunnah. Untuk memadukan pemikiran, rasa, suara, dan usaha dalam mengembalikan umat kepada al-Qur'an dan al-Sunnah serta terpeliharanya atsar (jejak) para mujahid (yang berjihad), maka didirikanlah jamiyyah (organisasi) Persatuan Islam (Persis). Atas dasar pemikiran tersebut serta memperhatikan keputusan Direktuur Van Justitie (Badan Kehakiman) Nomor A 43/30/20 tanggal 24 Agustus 1939, maka ditetapkan Nizham Jamiyyah Persis berupa Qanun Asasi dan Qanun Dakhili (Qanun, 2005).

Pendahuluan Qanun Asasi Persis di atas, menegaskan bahwa Persis merupakan organisasi yang menginginkan penguatan dan pelestarian kaum pembaharu. Suara untuk pemikiran yang melakukan proses pembaharuan harus disatukan dan diintegrasikan ke dalam institusi yang memiliki ciri khas utama selalu merujuk kepada al-Qur'an dan al-Sunnah. Misi yang dibangun oleh Persis sebagai organisasi adalah berbagai upaya pemberantasan taklid, bid'ah, khurafat, syirik, dan fanatisme madzhab. Misi tersebut harus dilakukan secara berjamaah, berimamah, dan berimarah. Semua anggota harus tunduk dan taat kepada aturan yang berlaku dan kepada pemimpin organisasi sepanjang tidak menyimpang dari al-Qur'an dan al-Sunnah (Islam PPP, 1984).

Misi pembaharuan Islam hendaknya diaplikasikan ke dalam kehidupan konkret di masyarakat sehingga pesan-pesan ajaran Islam itu mudah untuk ditiru oleh masyarakat secara umum. Agar bentuk dan model perilaku sosial itu seragam, satu suara, satu rasa, satu warga dan satu usaha, maka harus mengikuti norma-norma yang berlaku dalam organisasi. Penegasan misi dalam Qanun Asasi ini, lebih mudah dimaknakan, bahwa secara kasat mata Persis sebagai organisasi berkehendak untuk melembagakan perilaku anggotanya dengan dibentuk secara langsung maupun tidak langsung oleh norma-norma yang berlaku dalam organisasi. Dengan demikian, perilaku institusional sosial keagamaan Persis telah direncanakan secara matang dalam misinya (Wawancara dengan DT, pengurus pusat Persis, 2/7/2017).

Setiap keluarga Persis akan memberikan pemahaman yang sama terhadap sumber ajaran Islam dan dalam penerapannya. Meskipun anggota Persis terdiri atas 
ulama dan masyarakat awam, efektivitas sosialisasi perilaku keagamaan tidak mendapatkan hambatan. Dorongan struktural telah membentuk karakteristik kultural yang kuat dengan simbolisasi keanggotaan yang diakui oleh seluruh anggota Persis dan sekaligus membedakan diri dari simbol-simbol perilaku sosial keagamaan selain Persis (Wawancara dengan AM, pengurus pusat Persis, 2/7/2017).

1. Integrasi kultural dalam kehidupan sosial keagamaan dan adaptabilitas di kalangan anggota Persis kemungkinan besar didorong oleh empat hal penting, yaitu:

2. Keyakinan yang mendalam dari anggota Persis terhadap organisasi Persis sendiri yang sejak berdirinya selalu berslogan kembali kepada al-Qur'an dan alSunnah;

3. Kepercayaan anggota Persis kepada ulama Persis yang dilembagakan dalam Dewan Hisbah yang menggali pesan-pesan Allah dan Rasulullah saw. dalam alQur'an dan al-Hadits;

4. Ketaatan anggota Persis dalam berimamah dan berimarah, yang berarti taat kepada pemimpin yang dipilih dan ditetapkan melalui musyawarah mufakat dalam muktamar; dan

5. Sikap partisipatif yang kuat terhadap perilaku sosial keagamaan kolektif dan homogen, demi memudahkan dalam mempraktekkan ajaran agama Islam itu sendiri (Wawancara dengan AM, pengurus pusat Persis, 2/7/2017).

Berdasarkan empat alasan di atas, kiranya dapat dipahami bahwa institusi Persis membentuk pola perilaku sosial keagamaan anggotanya secara efektif. Pola perilaku sosial keagamaan terbentuk dengan adanya interaksi fungsional melalui kaidah dan peraturan-peraturan yang dijadikan term of referrence yang menjelma sebagai rujukan perilaku sosial keagamaan. Dorongan intelektual dan dorongan emosional dalam bertindak tidak lagi murni lahir dari individunya, melainkan merupakan citra intelektual dan citra emosional religius institusional.

Pemahaman di atas, dapat dijadikan alasan untuk pengkajian lebih mendalam, bahwa pemberantasan statisme pemikiran dalam Islam, taklid, fanatisme madzhab dan mistisisme, dengan cara membentuk organisasi yang secara sistemik melakukan proses pemolaan perilaku sosial keagamaan secara struktural maupun kultural, akan kembali 
membentuk fanatisme institusional dan taklid yang juga merupakan proses perwujudan perilaku institusional dengan pelemahan dinamika intelektual setiap potensi individu anggota Persis sendiri.

Proses internalisasi ajaran agama yang didukung oleh struktur kepemimpinan dalam organisasi, norma-norma yang mengikat dan menggiring ke arah pola interaksi satu arah dan melahirkan solidaritas organis di kalangan anggota Persis, dapat diperkirakan akan membentuk perilaku sosial keagamaan yang bersifat kolektif, homogen dan merupakan karakteristik penting dalam konteks perilaku institusional. Terutama dalam mendudukkan makna agama sebagai ajaran yang sakral dan imanen, serta makna agama dalam realitas hidup dan realitas pelaksanaannya yang beragam (Wawancara dengan BK, pengurus pusat Persis, 2/7/2017).

Persatuan Islam memiliki pemikiran yang khas dengan menempatkan dirinya sebagai paham keagamaan Islam yang puritan di Indonesia. Hal ini dibuktikan dengan setiap doktrin yang diterapkan pada berbagai persoalan yang dihadapi umat Islam di Indonesia. Pedoman pokok yang dianut Persatuan Islam mengandung prinsip-prinsip ini secara konkret tertulis dalam Qanun Asasi / Qanun Dakhili Persatuan Islam.

Persatuan Islam memiliki orientasi pemikiran yang bersifat puritan, yakni paham pemurnian Islam. Pemahaman keislaman yang bercorak puritan ini merupakan respon terhadap kecenderungan pemikiran yang dianut oleh kaum muslimin di Indonesia, yakni pemahaman keislaman yang bercorak kultural, yang lebih dikenal dengan Islam tradisionalis. Dalam pandangan Persatuan Islam, kaum muslimin Indonesia telah mempertahankan tradisi-tradisi yang diwariskan ulama terdahulu baik berupa pandangan-pandangan maupun metode berpikir para ulama klasik yang terdapat dalam kitab-kitab fiqih (Federspiel, 1970).

Al-Quran dan al-Hadits memiliki arti yang amat penting bagi Persatuan Islam, karena kedua sumber ini mempresentasikan Islam dalam bentuknya yang murni, dan dalam bentuk itulah Islam dapat diadaptasi ke berbagai kondisi dan konsep yang berlaku di dunia modern. Persatuan Islam berpandangan bahwa para sarjana tradisionalis telah mengabaikan dua sumber ini, dan secara keliru menekankan pentingnya interpretasi para fuqaha dan teolog muslim (mutakallimun) (Federspiel, 2001). 
Dalam aktivitas penyebaran al-Quran dan al-Sunah sebelum berdirinya lembaga-lembaga pendidikan Persatuan Islam, pelajaran-pelajaran agama dan ilmuilmu lainnya diberikan dalam pertemuan-pertemuan dan ceramah-ceramah. Acara tersebut lebih sering diselenggarakan oleh anggota secara pribadi daripada diorganisasikan secara resmi oleh Persatuan Islam. Baru kemudian setelah A. Hassan bergabung dalam aktivitas Persatuan Islam maka penyebaran paham al-Quran dan alSunah semakin meluas terutama setelah didirikannya kelas pendidikan akidah dan ibadah. Aktivitas penyelenggaraan kelas pendidikan akidah dan ibadah serta kursuskursus tersebut telah dimulai sejak tahun 1924 (Federspiel, 1970).

Hampir semua lembaga pendidikan Persatuan Islam didirikan atas keinginan dan kebutuhan jamaah di tingkat grassroots. Oleh karena itu, lembaga pendidikan Persatuan Islam secara relatif menjadi lebih otonom dan mandiri sehingga tidak terjadi dominasi institusi organisasi. Kenyataan tersebut telah memberikan blessing in disguise, karena setiap pesantren Persatuan Islam dapat membuat pola pengajaran yang lebih kreatif dan inovatif yang pada akhirnya madrasah/ pesantren Persatuan Islam senantiasa diminati stakeholder-nya dan dapat "hidup" tanpa bantuan dari induk organisasi atau pemerintah (Wawancara dengan AM, pengurus pusat Persis, 2/7/2017).

Dengan demikian, secara real lembaga pendidikan Persatuan Islam telah lama menerapkan manajemen berbasis sekolah (school-based management) dan berbasis kebutuhan masyarakat (community-based management) yang saat ini sedang dirintis oleh pemerintah sebagai jawaban terhadap tuntutan desentralisasi pendidikan. Artinya lembaga pendidikan Persatuan Islam telah lebih maju selangkah dibandingkan dengan sistem persekolahan yang diselenggarakan oleh pemerintah pada saat itu (Wawancara dengan DT, pengurus pusat Persis, 2/7/2017).

Berbeda dengan sistem pesantren salafiah (tradisional) yang menggunakan sistem bandongan dan sorogan, sistem pengajaran (paedagogik) yang digunakan di pesantren Persatuan Islam pada umumnya sama dengan sistem persekolahan umum dengan struktur yang sistematis dan modern. Sistem tersebut jelas mempermudah dalam pencapaian target kuantitatif dan dapat meminimalisasikan pengulangan yang tidak perlu (Mustari \& Rahman, 2010). 
Sebagaimana sistem pengajaran di sekolah umum, kelemahannya adalah menekankan pada semangat kompetitif melalui sistem ranking sehingga melahirkan peserta didik yang menang (winner) dan peserta didik yang kalah (looser) yang secara psikologis kurang menguntungkan bagi perkembangan mental peserta didik, padahal di negara-negara maju model kompetitif telah lama diganti dengan model kolaboratif (cooperative learning) yang memungkinkan semua peserta didik dengan semangat saling membantu untuk mengembangkan dirinya semaksimal mungkin (Mustari \& Rahman, 2014).

Dengan demikian, pesantren Persatuan Islam memoles wajah baru, baik sebagai organisasi maupun sebagai lembaga pendidikan yang mampu mencitrakan dirinya sebagai lembaga pendidikan inklusif. Juga adanya kesepahaman akan perlunya kebebasan dalam arti positif untuk mengkaji dan menyampaikan gagasan baru yang inovatif sehingga mendorong kreatifitas peserta didik. Bahkan untuk membantu menstimulasi keseimbangan kognitif dengan kecerdasan emosional tidak ada salahnya untuk memasukkan seni dan musik dalam tradisi kepesantrenan. Selain itu, kurikulum dan silabus pembelajaran lembaga pendidikan Persatuan Islam yang pada umumnya overload dan tidak memberikan ruang yang memadai untuk melakukan pencerahan dan pembaharuan, kini telah mengadopsi kurikulum nasional yang ditetapkan berdasarkan Undang-Undang Sistem Pendidikan Nasional. Ini menjadi bagian penting terjadinya perubahan pola pendidikan yang ekslusif menjadi inklusif. Dengan demikian, kepercayaan publik kepada lembaga pendidikan yang dikelola Persatuan Islam semakin tinggi mengingat lulusannya sejajar dengan lembaga pendidikan lainnya di Indonesia. Pesantren Persatuan Islam tidak hanya memberi kontribusi pada pendidikan nasional, melainkan juga pada proses santrinisasi masyarakat Muslim (Wawancara dengan IL, pengurus pusat Persis, 2/7/2017).

Arah pendidikan yang dikelola Persatuan Islam sejalan dengan pendidikan nasional yang diselenggarakan oleh pemerintah maupun swasta di Indonesia, yang bertujuan membentuk manusia yang memiliki kecerdasan yang tinggi, keterampilan, dan kemampuan sesuai dengan kekuatan jasmaninya, membentuk manusia Indonesia yang memiliki kemampuan, kecerdasan yang handal, dan mengembangkan potensi keimanan dan ketaqwaan, membentuk akhlak karimah, mempunyai rasa cinta tanah air, bangsa dan negara, menghormati sesama warga negara dan bangsa-bangsa lain, 
berbudi luhur, serta memiliki sikap mental demokratis dan bertanggung jawab. Pendidikan Persatuan Islam bertujuan menghasilkan manusia yang beriman tinggi serta kecerdasan dan keterampilan yang sangat dibutuhkan dalam masa pembangunan yang sedang dilaksanakan oleh bangsa Indonesia (Wawancara dengan DT, pengurus pusat Persis, 2/7/2017).

Terbangunnya gerakan inkusivisme terlihat dalam kaitannya dengan hubungan sosial di kalangan anggota Persatuan Islam. Masyarakat sebagai obyek sekaligus sebagai subyek memiliki makna fungsional bagi tersampaikannya dakwah Persatuan Islam. Hubungan Persatuan Islam dengan masyarakat dalam seluruh proses kegiatan keagamaan yang telah direncanakan dan diusahakan secara sengaja dan bersungguhsungguh, disertai pembinaan secara kontinu untuk mendapatkan simpati dari masyarakat pada umumnya, dan khususnya masyarakat yang berkepentingan langsung dengan Persatuan Islam. Simpati masyarakat akan tumbuh melalui upaya-upaya Persatuan Islam dalam menjalin hubungan secara intensif dan proaktif di samping membangun citra lembaga yang baik (Wawancara dengan IL, pengurus pusat Persis, 2/7/2017).

Hubungan Persatuan Islam dengan masyarakat bertujuan menggairahkan masyarakat untuk menjalin hubungan dengan Persatuan Islam, mendapatkan umpan balik (feedback) dari masyarakat atas kebijakan-kebijakan yang ditempuh Persatuan Islam, menunjukkan transparansi pengelolaan lembaga sehingga memiliki akuntabilitas publik yang tinggi, dan mendapatkan dukungan real dari masyarakat terhadap kelangsungan Persatuan Islam sebagai ormas Islam di Indonesia (Wawancara dengan SF, pengurus wilayah Persis Jawa Barat, 3/7/2017).

Persatuan Islam melakukan upaya menjalin hubungan dengan masyarakat melalui hal-hal sebagai berikut: 1) Membangun citra yang baik dengan masyarakat. 2) Membangun kepercayaan masyarakat terhadap Persatuan Islam dengan menunjukkan keteladanan kepada masyarakat luas. 3) Menyosialisasikan dan memublikasikan program Persatuan Islam kepada masyarakat luas terutama yang sesuai dengan tuntunan ajaran Islam. 4) Menjalin hubungan dengan semua ormas Islam (Wawancara dengan IL, pengurus pusat Persis, 2/7/2017).

Hubungan Persatuan Islam dengan masyarakat membuka dakwah lintas kultural, artinya Persatuan Islam yang dikenal eksklusif berubah menjadi inklusif. 
Berjalan seiring dengan ormas Islam lainnya, Persis hari ini tidak membid'ahkan perilaku keagamaan ormas Islam lainnya. Begitu pula, Persis sekarang bekerja sama dalam menjawab kebutuhan umat Islam dengan menjadi pengurus di Majelis Ulama Indonesia juga Forum Pondok Pesantren se-Indonesia (Wawancara dengan DT, pengurus pusat Persis, 2/7/2017).

Persatuan Islam sebagai ormas Islam yang dahulu selalu menolak bantuan dana dari pemerintah, memakruhkan menjadi pegawai negeri sipil, dan cenderung mudah memandang kelompok Islam lain sebagai pelaku taqlid, khurafat, dan bid'ah, kini tidak terdengar lagi melakukan hal-hal tersebut. Dulu Persis bahkan memandang musyrik menghormat bendera saat melaksanakan upacara, kini tidak terdengar lagi. Kesadaran Persatuan Islam tampak dalam memahami segala persoalan secara bijak, baik melalui pemahaman yang metodologis dan sosiologis. Kemajuan pemahaman dalam menganalisis setiap persoalan yang ada menunjukkan moderasi berpikir kaum inklusivistik, karena setiap kesimpulan hasil pemahaman amat bergantung pada sudut pandang masing-masing ulama dan intelektual. Oleh karena itu pengayaan keilmuan dalam pelbagai kajian keislaman selalu dilengkapi dengan keilmuan lainnya, sebagaimana pemahaman filosofis, sosiologis, dan politik pada setiap permasalahan yang timbul di tengah kehidupan masyarakat Islam (Wawancara dengan AM, pengurus pusat Persis, 2/7/2017).

\section{Simpulan}

Gerakan membuka diri dan menempatkan keberagamaan dalam kebersamaan sosial merupakan cara pandang dan gerakan yang mulai dikembangkan oleh jamaah (anggota) Persis, terutama di kalangan Persis Muda yang intelek dan berwawasan moderat. Hal demikian telah membuka hubungan harmonis dengan ormas Islam lainnya, sehingga tema perbincangan di kalangan jamaah Persis dan selain Persis lebih didominasi oleh tema sosial, ekonomi, politik, dan kebudayaan yang semakin mendesak memerlukan jawaban yang berbasis kepada ajaran agama Islam. Dengan kata lain, tema tersebut membuka sikap inklusivisme jamaah Persis terhadap jamaah ormas lainnya seperti Nahdhatul Ulama dan Muhammadiyah. 
ARTIKEL

\section{DAFTAR PUSTAKA}

Ash-Shiddieqy, M. H. (1997). Pokok-Pokok Pegangan Imam Maz̧hab. Semarang: Rizki Putra.

Chalidjah Hasan. (1990). Persatuan Islam dan Pembabaruannya. Bandung: Lembaga Penelitian IAIN Sunan Gunung Djati.

Dulkiah, M. (2018). TRUST BUILDING PEDAGANG KAIN DAN PAKAIAN DI CIREBON. TEMALI: Jurnal Pembangunan Sosial, 1(1), 1-20.

Federspiel, Howard M. (1970). Persatuan Islam, Islamic Reform in Twentieth Century Indonesia. New York: Cornell University.

Federspiel, Howard M. (2001). Islam and Ideology in the Emerging Indonesian State (Leiden: Brill. 2001), vol. 78.

Hamka, R. (1989). Islam dan era Informasi. Pustaka Panjimas.

Hodgson, M. G. (2009). The Venture of Islam, Volume 1: The Classical Age of Islam. University of Chicago press.

Islam, P. P. P. (1984). Tafsir Qanun Asasi dan Dakbili Persatuan Islam.

Luthans, Fred. (2011). Organizational Behavior. $12^{\text {th }}$ edition. New York: McGraw-Hill.

Mustari, M., \& Rahman, M. T. (2010). Peranan pesantren dalam pembangunan pendidikan masyarakat desa. MultiPress.

Mustari, M., \& Rahman, M. T. (2014). Nilai Karakter Untuk Refleksi Pendidikan. Jakarta: PT Raja Grafindo Persada.

Qanun, Q. A. Q. D. P. (2005). Asasi-Qanun Dakbili Pedoman Kerja Program Jihad 20052010 Persatuan Islam.

Rahman, M. T. (2010). Social Justice in Western and Islamic Thought: A Comparative Study of John Rawl's and Sayyid Qutb's Theories of Social Justice (Doctoral dissertation, Jabatan Akidah dan Pemikiran Islam, Akademi Pengajian Islam, Universiti Malaya).

Rahman, M. T. (2016). ISLAM AS AN IDEAL MODERN SOCIAL SYSTEM (A Study of Ali Shariati's Thought). JISPO: Jurnal Ilmu Sosial dan Ilmu Politik, 6(1), 42-51.

Rahman, T. (2014). 'Indianization'of Indonesia in an Historical Sketch. International Journal of Nusantara Islam, 1(2), 56-64.

Sari, A. L. (2017). THE ROLE OF SOCIAL WORKERS IN THE DEVELOPMENT OF TOURISM VILLAGES. JISPO: Jurnal Ilmu Sosial dan Ilmu Politik, 7(2), 1-23.

Turner, Bryan S. (1991). Religion and Social Theory. Second Edition. London: Sage Publication.

Umar, Salim. (1995). Persatuan Islam: Pembaharuan dan Pengarubnya Di Jawa Barat. Bandung: Makalah, tidak diterbitkan.

Weber, Max. (1966). The Sociology of Religion. London: Unwim Paperbacks. 